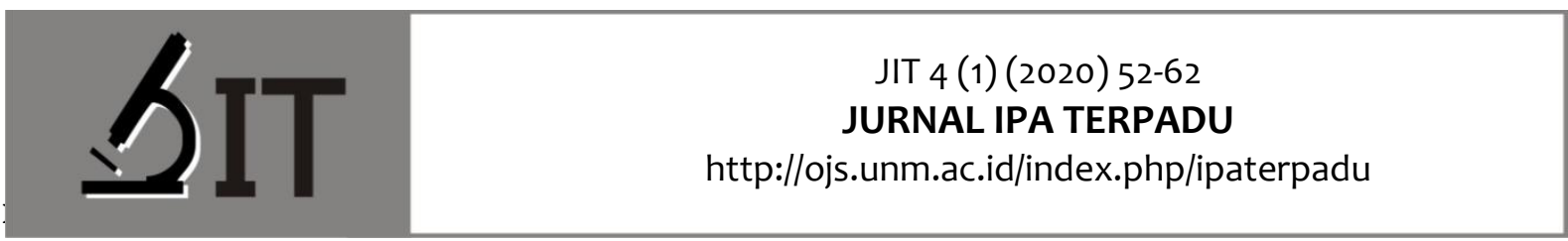

p-ISSN : 2597-8977

e-ISSN : 2597-8985

Abdul Rozzaq N. L.*) Prodi Pendidikan IPA FMIPA Universitas Negeri Makassar

Hasanuddin Prodi Pendidikan IPA FMIPA Universitas Negeri Makassar

Muhammad Aqil Rusli Prodi Pendidikan IPA FMIPA Universitas Negeri Makassar

*) Correspondence Author: rozzaq3097@gmail.com

\section{HUBUNGAN SIKAP ILMIAH DENGAN HASIL BELAJAR IPA PESERTA DIDIK KELAS VIII SMP NEGERI 33 MAKASSAR}

Abstrak: Penelitian ini bertujuan untuk : (1) Mendeskripsikan sikap ilmiah peserta didik kelas VIII SMP Negeri 33 Makassar, (2) Mendeskripsikan hasil belajar IPA peserta didik kelas VIII SMP Negeri 33 Makassar, dan (3) Menguji adanya hubungan antara sikap ilmiah dengan hasil belajar IPA peserta didik kelas VIII SMP Negeri 33 Makassar. Penelitian ini merupakan penelitian survey dengan menggunakan desain penelitian korelasional. Populasi dalam penelitian ini adalah seluruh peserta didik kelas VIII SMP Negeri 33 Makassar tahun ajaran 2019/2020 yang berjumlah 350 peserta didik. Penelitian ini menggunakan pengambilan sampel dengan rumus Slovin dengan kesalahan 5\% sehingga di dapatkan sampel sebanyak 187 peserta didik. Instrumen penelitian adalah angket sikap ilmiah dan tes hasil belajar IPA yang berbentuk soal pilihan ganda sebanyak 25 item yang telah divalidasi ahli. Hasil penelitian ditemukan : (1) Sikap ilmiah peserta didik kelas VIII SMP Negeri 33 Makassar memiliki rata-rata skor keseluruhan sebesar 105,98 yang termasuk dalam kategori sedang.; (2) Hasil belajar IPA peserta didik kelas VIII SMP Negeri 33 Makassar memiliki rata-rata keseluruhan skor sebesar 13,35 termasuk dalam kategori sedang.; (3) Terdapat hubungan yang signifikan antara sikap ilmiah dengan hasil belajar IPA peserta didik kelas VIII SMP Negeri 33 Makassar sebesar 0,333 termasuk dalam kategori rendah.

Kata Kunci: Sikap IImiah, Hasil Belajar IPA.

Abstract: Abstract: This study aims to: (1) describe scientific attitudes of eighth grade students of SMP Negeri 33 Makassar, (2) describe science learning outcomes of eighth grade students of SMP Negeri 33 Makassar, and (3) examine the relationship between scientific attitudes and science learning outcome of eighth grade students of SMP Negeri 33 Makassar. This is a survey research using a correlational design. Population was all 350 eighth grade students of SMP Negeri 33 Makassar 2019/2020 academic year. Sampling used Slovin formula with a 5\% error with 187 students as sample is obtained. Instrument was a scientific attitude questionnaire and a science learning outcome test in 25 items multiple choice questions that had been validated by experts. The results were: (1) The scientific attitude of eighth grade students of SMP Negeri 33 Makassar had 105,98 average total score which was included in medium category; (2) The science learning outcomes of eighth grade students of SMP Negeri 33 Makassar had a 13.35 average total score which was included in medium category; (3) There is a significant relationship between scientific attitude and science learning outcomes of eighth grade students of SMP Negeri 33 Makassar, which is 0.333 , including in low category.

Keyword: Scientific Attitudes, Science Learning Outcomes. 


\section{PENDAHULUAN}

Ilmu pengetahuan memiliki bermacam-macam jenis dan tingkatan, yang tersusun dalam dunia pendidikan. Pendidikan sendiri adalah usaha sadar dan bertujuan untuk mengembangkan kualitas manusia (Djamarah S. B., 2006). Salah satu yang terpenting dan memiliki pengaruh yang besar terhadap perkembangan dalam kehidupan manusia adalah Ilmu Pengetahuan Alam (IPA). IPA adalah pengetahuan manusia tentang alam yang diperoleh dengan cara yang terkontrol, selain sebagai produk yaitu pengetahuan manusia. Sains atau IPA juga sebagai proses yaitu bagaimana cara mendapatkan pengetahuan tersebut (Asy'ari, 2006). IPA berkaitan dengan cara mencari tahu tentang alam secara sistematis, sehingga IPA bukan hanya penguasaan kumpulan pengetahuan yang berupa fakta-fakta, konsep-konsep atau prinsip-prinsip saja tetapi juga merupakan suatu penemuan.

Kurikulum 2013 merupakan pembelajaran penemuan sebuah konsep yang lebih menekankan pendekatan ilmiah pada proses pembelajaran. Pendekatan ilmiah meliputi kegiatan mengamati, menanya, mencoba, mengolah, menyajikan, menyimpulkan, dan mencipta. Oleh karena itu, pembelajaran IPA lebih menekankan pada pemberian pengalaman belajar secara langsung melalui penggunaan dan pengembangan proses. Dalam proses pembelajaran IPA sendiri peserta didik dituntut untuk memahami materi secara mendalam dan cermat, tidak sekedar menghafal teori maupun rumus tertentu. Untuk itu, dibutuhkan sikap yang dapat mendorong peserta didik agar lebih aktif dan efektif dalam memahami materi pembelajaran, dalam hal ini sikap ilmiah peserta didik. Dalam sikap ilmiah sendiri terdapat beberapa indikator di antaranya sikap rasa ingin tahu dan sikap ketekunan. Sikap-sikap inilah yang harus dimunculkan dan dikembangkan oleh peserta didik dengan peran para pendidik sehingga terwujudnya peserta didik yang unggul. Hal ini sesuai dengan Peraturan Pemerintah Nomor 32 Tahun 2013 tentang Standar Nasional Pendidikan yang menjelaskan bahwa standar kompetensi lulusan adalah kriteria mengenai kualifikasi kemampuan lulusan yang mencakup sikap, pengetahuan, dan keterampilan.

Menurut Trianto (2011), hakikat IPA merupakan ilmu pengetahuan yang mempelajari gejalagejala atas dasar sikap ilmiah dan hasilnya terwujud sebagai produk ilmiah yang tersusun atas tiga komponen terpenting berupa konsep, prinsip, dan teori. Lebih lanjut Purnama (2008) menjelaskan dalam pembelajaran sangat diperlukan sikap ilmiah karena dapat memotivasi kegiatan belajarnya. Pada sikap ilmiah terdapat gambaran bagaimana seharusnya bersikap dalam belajar, menanggapi suatu permasalahan, melaksanakan tugas, dan mengembangkan diri. Hal ini tentunya sangat mempengaruhi hasil belajar peserta didik ke arah yang positif. Melalui penanaman sikap ilmiah dalam pembelajaran maka peserta didik lebih dapat belajar untuk memahami dan menemukan. Sikap ilmiah itu sendiri antara lain ialah sikap jujur, teliti, tanggung jawab, disiplin, dan rasa ingin tahu.

Berdasarkan penelitian tentang sikap ilmiah, di antaranya hasil penelitian Yunita , Fakhruddin Z dan Nor (2013) yang menunjukkan bahwa terdapat hubungan yang positif dan signifikan antara sikap ilmiah peserta didik dan hasil belajar fisika peserta didik. Hal ini berarti bahwa semakin positif sikap ilmiah peserta didik, maka nilai hasil belajar fisika peserta didik semakin tinggi. Demikian pula sebaliknya, semakin negatif sikap ilmiah peserta didik, maka nilai hasil belajar fisika peserta didik akan semakin rendah.

Sikap ilmiah merupakan sikap yang harus ada pada diri seorang ilmuwan atau akademisi ketika menghadapi persoalan-persoalan ilmiah. Sikap ilmiah ini perlu dibiasakan dalam berbagai forum ilmiah, misalnya dalam diskusi, seminar, loka karya, dan penulisan karya ilmiah (Anwar, 2009). Sikap ilmiah dalam pembelajaran sains sering dikaitkan dengan sikap terhadap sains. Keduanya saling berhubungan dan mempengaruhi perilaku. Sikap ilmiah dibedakan dari sekedar sikap terhadap sains, karena sikap terhadap sains hanya terfokus pada peserta didik menyukai atau tidak menyukai pembelajaran sains. Tentu saja sikap positif terhadap pembelajaran sains akan 
memberikan kontribusi tinggi dalam pembentukan sikap ilmiah peserta didik tetapi masih ada faktor lain yang memberikan kontribusi yang cukup berarti (Handayani, 2014).

Pengelompokan sikap ilmiah oleh para ahli cukup bervariasi, meskipun jika dikaji lebih jauh hampir tidak ada perbedaan yang berarti. Variasi muncul hanya dalam penempatan dan penamaan sikap ilmiah yang lebih ditonjolkan. Adapaun indikator sikap ilmiah menurut Harlen dalam Anwar (2009), indikator sikap ilmiah yang dimaksud adalah sebagai berikut:

1) Sikap ingin tahu

2) Sikap respek terhadap data/fakta

3) Sikap berpikir kritis

4) Sikap penemuan dan kreativitas

5) Sikap berpikiran terbuka dan kerjasama

6) Sikap ketekunan

Pengembangan dan penilaian sikap ilmiah penting dilaksanakan di dalam kelas karena berkontribusi terhadap kemampuan peserta didik dalam mengikuti proses pembelajaran. Hasil belajar yang diharapkan dicapai oleh peserta didik adalah terjadinya perubahan perilaku secara holistik. Pandangan yang menitik beratkan hasil belajar dalam bentuk penambahan pengetahuan saja merupakan wujud dari pandangan yang sempit, karena belajar dan pembelajaran harus dapat menyentuh dimensi-dimensi individual anak secara menyeluruh, termasuk dimensi emosional yang dalam waktu cukup lama luput dari perhatian. Hal ini dipandang semakin penting karena dari berbagai hasil penelitian juga menunjukan bahwa keberhasilan belajar ternyata lebih banyak ditentukan oleh faktor-faktor emosi antara lain daya tahan, keuletan, ketelitian, disiplin rasa tanggung jawab, kemampuan menjalin kerjasama, motivasi yang tinggi serta beberapa dimensi emosional lainnya (Aunurrahman, 2012).

Hasil wawancara dengan guru bidang studi IPA yang mengajar di kelas VIII SMPN 33 Makassar diketahui bahwa sikap ilmiah peserta didik belum pernah dilakukan pengujian. Penilaian yang dilakukan oleh guru sebatas mengukur dimensi pengetahuan peserta didik. Berdasarkan uraian sebelumnya tentang pentingnya sikap ilmiah dikembangkan dan dinilai dalam pembelajaran serta hubungannya dengan hasil belajar peserta didik maka peneliti melakukan penelitian mengenai hubungan antara sikap ilmiah dengan hasil belajar yang berjudul "Hubungan Antara Sikap Ilmiah Dengan Hasil Belajar IPA Peserta Didik Kelas VIII SMP NEGERI 33 Makassar”.

\section{METODE}

Jenis penelitian yang digunakan adalah metode penelitian survey. Penelitian ini merupakan penelitian korelasi, karena di dalam penelitian ini bertujuan untuk menemukan ada tidaknya hubungan antara sikap ilmiah dengan hasil belajar IPA peserta didik kelas VIII SMP Negeri 33 Makassar. Penelitian korelasi adalah suatu penelitian yang melibatkan tindakan pengumpulan data guna menentukan, apakah ada hubungan dan tingkat hubungan antara dua variabel atau lebih.

Penelitian ini dilaksanakan di SMP Negeri 33 Makassar, Kecamatan Rappocini, Provinsi Sulawesi Selatan. Waktu penelitian dilakukan pada bulan Mei, semester ganjil tahun ajaran 2019/2020. Populasi dalam penelitian ini adalah seluruh peserta didik kelas VIII SMP Negeri 33 Makassar tahun ajaran 2019/2020 yang terdiri dari sepuluh (10) kelas dengan jumlah 350 Peserta didik. Penelitian ini menggunakan rumus Slovin karena dalam penarikan sampel, jumlahnya harus representatif agar hasil penelitian dapat digeneralisasikan dan perhitungannya tidak memerlukan tabel jumlah sampel, namun dapat dilakukan dengan rumus dan perhitungan sederhana. Berdasarkan hasil perhitungan diperoleh sampel penelitian sebanyak 187 peserta didik.

Instrumen yang digunakan dalam penelitian ini adalah angket sikap ilmiah dan tes hasil belajar IPA. Angket sikap ilmiah peserta didik bertujuan untuk mengetahui seberapa tinggi tingkat sikap ilmiah peserta didik kelas VIII SMP Negeri 33 Makassar yang berupa item-item pernyataan 
yang dikelompokkan menurut indikator yang dijadikan fokus perhatian oleh peneliti. Penskoran digunakan skala Likert dapat dilihat pada tabel berikut.

Tabel 1. Pedoman Penskoran Jawaban Skala Likert

\begin{tabular}{ccc}
\hline Jawaban & Skor Jawaban Positif & Skor Jawaban Negatif \\
\hline Sangat Setuju (SS) & 4 & 1 \\
Setuju (S) & 3 & 2 \\
Tidak Setuju (TS) & 2 & 3 \\
Sangat Tidak Setuju (STS) & 1 & 4 \\
\hline
\end{tabular}

Kategori sikap ilmiah dengan kriteria sangat tinggi, tinggi, sedang, rendah, dan sangat rendah dibuat berdasarkan pengkategorian sebagai berikut.

Tabel 2. Pedoman Pengkategorian Angket Sikap IImiah

\begin{tabular}{cc}
\hline Tingkat Penguasaan & Kriteria \\
\hline $90 \%-100 \%$ & Sangat Tinggi \\
$80 \%-89 \%$ & Tinggi \\
$70 \%-79 \%$ & Sedang \\
$60 \%-69 \%$ & Rendah \\
$<59 \%$ & Sangat Rendah \\
\hline
\end{tabular}

Tes hasil belajar peserta didik digunakan untuk mengumpulkan data mengenai nilai hasil belajar peserta didik kelas VIII SMP Negeri 33 Makassar tahun ajaran 2019/2020 untuk mata pelajaran IPA. Soal berbentuk pilihan ganda sebanyak 25 item soal, dengan penskoran 1 jika menjawab benar dan o jika menjawab salah. Kategori skor hasil belajar IPA dapat dilihat pada Tabel 3 berikut.

Tabel 3. Pedoman Pengkategorian Skor Hasil Belajar IPA

\begin{tabular}{cc}
\hline Tingkat Penguasaan & Kriteria \\
$90 \% \leq x$ & Sangat Tinggi \\
$75 \% \leq x<90 \%$ & Tinggi \\
$50 \% \leq x<75 \%$ & Sedang \\
$25 \% \leq x<50 \%$ & Rendah \\
$0 \% \leq x<25 \%$ & Sangat Rendah \\
\hline & (Ratumanan \& Laurens, 2003)
\end{tabular}

Penelitian ini menggunakan analisis deskriptif dan analisis inferensial. Data yang telah diperoleh kemudian dianalisis secara deskriptif dengan tujuan untuk menggambarkan hal-hal yang penting dari objek yang diteliti termasuk distribusi frekuensi, mean, median, modus, range, kategori dan persentase dari setiap variabel. Analisis inferensial dilakukan untuk menguji hipotesis penelitian dan dari hasil analisis itu akan ditarik suatu kesimpulan. Pengujian yang dilakukan dalam penelitian ini termasuk uji normalitas, uji Korelasi Product Moment untuk melihat hubungan dua variabel, uji signifikasi Korelasi Prouct Moment untuk menentukan hubungan yang diperoleh dapat diterapkan untuk seluruh populasi, dan uji regresi liniear untuk menentukan hubungan yang positif atau negatif antara dua variabel. 


\section{HASIL DAN PEMBAHASAN}

\section{Hasil Penelitian}

\section{a. Analisis Statistik Deskriptif}

Hasil analisis deskriptif yang berkaitan dengan sikap ilmiah peserta didik dapat dilihat pada Tabel 4 berikut.

Tabel 4. Hasil Analisis Deskriptif Sikap Ilmiah

\begin{tabular}{clc}
\hline No. & \multicolumn{1}{c}{ Statistik } & Hasil \\
\hline 1. & Jumlah responden & 187 \\
2. & Skor tertinggi yang diperoleh responden & 125 \\
3. & Skor terendah yang diperoleh responden & 81 \\
4. & Skor Maksimal & 144 \\
5. & Skor Minimal & 36 \\
6. & Rata-rata & 105,98 \\
7. & Standar Deviasi $(\mathrm{s})$ & 9,09 \\
8. & Varians $\left(\mathrm{s}^{2}\right)$ & 82,62 \\
\hline
\end{tabular}

Berdasarkan pada Tabel 4 terlihat bahwa tidak ada responden yang mencapai skor maksimal 144 namun juga jauh dari skor minimal 36. Hal ini ditunjukkan dari skor rata-rata sikap ilmiah peserta didik yaitu 105,98. Untuk mengetahui kategori dari skor rata-rata sikap ilmiah peserta didik maka harus merujuk pada Tabel 2 tentang pedoman pengkategorian skor sikap ilmiah. Berdasarkan pedoman tersebut, maka diperoleh kategori dari skor sikap ilmiah yang diperoleh peserta didik ditunjukkan pada Tabel 5 berikut.

Tabel 5. Kategori Skor Sikap Ilmiah Peserta Didik

\begin{tabular}{cc}
\hline Rentang Skor & Kriteria \\
\hline $129-144$ & Sangat Tinggi \\
$115-128$ & Tinggi \\
$100-114$ & Sedang \\
$86-99$ & Rendah \\
$<86$ & Sangat Rendah \\
\hline
\end{tabular}

Berdasarkan Tabel 5, kategori skor sikap ilmiah peserta didik berada pada kriteria sedang. Sikap ilmiah terdiri dari beberapa indikator. Hasil analisis setiap indikator sikap Ilmiah peserta didik dapat terlihat pada Tabel 6 .

Tabel 6. Hasil Analisis Tiap Indikator Sikap Ilmiah

\begin{tabular}{ccc}
\hline No. & Indikator & Skor Rata-Rata \\
\hline 1. & Sikap Ingin Tahu & 18,91 \\
2. & Sikap Berpikir Kritis & 16,27 \\
3. & Sikap Ketekunan & 18,02 \\
4. & Sikap Berpikiran Terbuka Dan Kerja Sama & 18,3 \\
5. & Sikap Penemuan Dan Berpikir Kreatif & 17,24 \\
6. & Sikap Menghargai Data Dan Fakta Hasil Percobaan & 17,25 \\
\hline
\end{tabular}


Setiap indikator sikap ilmiah memiliki skor maksimal 24. Jika skor rata-rata tiap indikator tersebut dilihat pada pengkategorian indikator sikap IImiah pada Tabel 2 maka indikator sikap ingin tahu termasuk dalam kategori tinggi, sikap berpikir kritis termasuk dalam kategori rendah dan sikap ketekunan termasuk dalam kategori sedang. Sedangkan untuk sikap berpikiran terbuka dan kerja sama termasuk dalam kategori sedang, sikap penemuan dan berpikir kreatif termasuk dalam kategori sedang serta sikap menghargai data dan fakta hasil percobaan termasuk dalam kategori sedang. Berikut Tabel 7 yang menunjukkan kategori tiap indikator sikap ilmiah peserta didik.

Tabel 7. Kategori Skor Tiap Indikator Sikap Ilmiah

\begin{tabular}{cc}
\hline Rentang Skor & Kriteria \\
\hline $22-24$ & Sangat Tinggi \\
$19-21$ & Tinggi \\
$17-18$ & Sedang \\
$14-16$ & Rendah \\
$<14$ & Sangat Rendah \\
\hline
\end{tabular}

Selain sikap ilmiah, variabel lain yang diteliti pada penelitian ini adalah hasil belajar IPA peserta didik. Hasil analisis deskriptif untuk hasil belajar IPA diuraikan pada Tabel 8 sebagai berikut.

Tabel 8. Hasil Analisis Deskriptif Skor Hasil Belajar IPA

\begin{tabular}{ccc}
\hline No. & Statistik & Hasil \\
\hline 1. & Jumlah responden & 187 \\
2. & Skor tertinggi yang diperoleh responden & 22 \\
3. & Skor terendah yang diperoleh responden & 6 \\
4. & Skor maksimal & 25 \\
5. & Skor minimal & 0 \\
6. & Rata-rata & 13,35 \\
7. & Standar Deviasi $(\mathrm{s})$ & 3,4 \\
8. & Varians $\left(\mathrm{s}^{2}\right)$ & 11,56 \\
\hline
\end{tabular}

Berdasarkan Tabel 8 skor tertinggi yang peserta didik peroleh pada tes hasil belajar IPA yaitu 22 dan skor terendah yaitu 6 . Hal ini menunjukkan bahwa skor tertinggi dari hasil belajar IPA peserta didik mendekati skor maksimal. Namun skor rata-rata hasil belajar IPA hanya sebesar 13,35. Dengan menggunakan pedoman pengkategorian skor hasil belajar pada Tabel 3 maka skor ratarata hasil belajar IPA peserta didik berada pada kriteria sedang. Tabel 9 berikut ini menunjukkan kategori skor hasil belajar IPA berdasarkan pedoman pada Tabel 3.

Tabel 9. Kategori Skor Hasil Belajar IPA

\begin{tabular}{cc}
\hline Rentang Skor & Kriteria \\
\hline $22,5 \leq X$ & Sangat Tinggi \\
$18,75 \leq X<22,75$ & Tinggi \\
$12,5 \leq X<18,75$ & Sedang \\
$6,25 \leq X<12,5$ & Rendah \\
$0 \leq X<6,25$ & Sangat Rendah \\
\hline
\end{tabular}




\section{b. Analisis Statistik Deskriptif}

Beberapa uji yang dilakukan pada penelitian ini di antaranya uji normalitas melalui uji Chi Kuadrat, uji korelasi Product Moment, uji signifikansi korelasi Product Moment dan uji regresi linier sederhana.

1) Uji Normalitas

Berikut uji normalitas untuk data sikap ilmiah peserta didik seperti yang ditunjukkan pada Tabel 7.

Tabel 7. Rekapitulasi Hasil Perhitungan Uji Normalitas Skor Sikap Ilmiah

\begin{tabular}{rccccc}
\hline Kelas VIII & $\mathbf{n}$ & Taraf Signifikan & $\chi^{2}$ hitung & $\chi^{2}$ tabel & Kesimpulan \\
\hline 350 & 187 & 0,05 & 12,118 & 14,067 & $\begin{array}{c}\text { Terdistribusi } \\
\text { Normal }\end{array}$ \\
\hline
\end{tabular}

Berdasarkan hasil uji normalitas pada Tabel 7 maka dapat disimpulkan bahwa data sikap ilmiah seluruh peserta didik kelas VIII SMP Negeri 33 Makassar tahun ajaran 2019/2020 terdistribusi normal. Sedangkan untuk uji normalitas data hasil belajar dapat dilihat pada Tabel 8 berikut.

Tabel 8. Rekapitulasi Hasil Perhitungan Uji Normalitas Skor Hasil Belajar IPA

\begin{tabular}{cccccc}
\hline Kelas VIII & $\mathbf{n}$ & Taraf Signifikan & $\chi^{2}$ hitung & $\chi^{2}$ tabel & Kesimpulan \\
\hline 350 & 187 & 0,05 & 5,089 & 14,067 & $\begin{array}{c}\text { Terdistribusi } \\
\text { Normal }\end{array}$ \\
\hline
\end{tabular}

Sama seperti hasil uji normalitas data sikap ilmiah, dari Tabel 8 juga dapat disimpulkan bahwa data hasil belajar peserta didik kelas VIII SMP Negeri 33 Makassar tahun ajaran 2019/2020 terdistribusi normal.

\section{2) Uji Korelasi}

Uji korelasi memperoleh nilai $r_{x y}=0,333$ di mana jika dilihat pada tabel tingkat hubungan berdasarkan interval korelasi, angka ini menunjukkan adanya hubungan yang rendah antara sikap ilmiah dengan hasil belajar peserta didik kelas VIII SMP Negeri 33 Makassar.

\section{3) Uji Signifikasi Korelasi}

Untuk menguji signifikasi hubungan atau dengan kata lain untuk menentukan hubungan yang ditemukan berlaku untuk semua populasi yang berjumlah 350 peserta didik, maka perlu diuji signifikasinya. Berdasarkan hasil perhitungan signifikasi korelasi product moment didapatkan nilai signifikasi atau $t_{\text {hitung }}$ sebesar 4,808. Harga thitung tersebut seanjutnya dibandingkan dengan harga $t_{\text {tabel. }}$ Untuk kesalahan $5 \%$ uji dua pihak dan dk $=n-2=187-2=185$, maka diperoleh $t_{\text {tabel }}$ sebesar 1,96.

Hasil analisis didapatkan $t_{\text {hitung }}$ sebesar 4,808 maka $t_{\text {hit }}>t_{\text {tabel }}=4,808>1,96$ maka $\mathrm{H}_{0}$ ditolak dan $\mathrm{H}_{\mathrm{a}}$ diterima artinya korelasi antara variabel $\mathrm{X}$ dengan $\mathrm{Y}$ signifikan, artinya koefisien tersebut dapat digeneralisasikan atau dapat berlaku pada populasi. 
Adapun hasil perhitungan pada uji persamaan regresi menunjukkan bahwa $\gamma=0,159$ $+0,124 X+\varepsilon$ yang berarti ketika sikap ilmiah peserta didik konstan maka rata-rata hasil belajar IPA peserta didik 0,159, sedangkan ketika sikap ilmiah peserta didik sebesar 0,124 menunjukkan bahwa setiap kenaikan 1 konstanta pada sikap ilmiah akan meningkatkan hasil belajar peserta didik sebesar 0,124 . Nilai koefisien determinasi $\left(R^{2}\right)$ diperoleh dari uji korelasi sebesar 0,111 berarti berarti bahwa $11,1 \%$, mencerminkan adanya pengaruh variabel lain yang telah teridentifikasi oleh teori tetapi tidak diteliti atau variabel lainnya yang belum teridentifikasi oleh teori dengan kesalahan/kekeliruan pengukuran, sehingga $\varepsilon=1-R^{2}=1-0,111=0,889$.

Menurut Sugiyono (2015) harga b merupakan fungsi dari koefisien korelasi. Bila koefisien korelasi tinggi, maka harga b juga besar, sebaliknya bila koefisien korelasi rendah maka harga b juga rendah (kecil). Selain itu bila koefisien korelasi negatif maka harga b juga negatif, dan sebaliknya bila koefisien korelasi positif maka harga b juga positif. Berdasarkan pernyataan tersebut dinyatakan bahwa sikap ilmiah berpengaruh positif dimana harga b pada persamaan regresi adalah 0,124 .

Berdasarkan hasil uji signifikan atau keberartian regresi diperoleh $F_{\text {hitung }}$ untuk keberartian regresi sebesar 22,578 dan $F_{\text {tabel }}$ sebesar 3,84 sehingga dapat dikatakan $F_{\text {hitung }}>F_{\text {tabel }}(\propto 0,05)=$ $22,578>3,84$. Dari hasil yang diperoleh dapat disimpulkan $\mathrm{H}_{\mathrm{o}}$ ditolak, yang berarti data tersebut memiliki pola regresi yang berarti atau signifikan. Jadi, terdapat hubungan yang signifikan antara sikap ilmiah dengan hasil belajar IPA peserta didik.

\section{Pembahasan}

Berdasarkan hasil analisis deskriptif menunjukkan bahwa sikap ilmiah peserta didik kelas VIII SMP Negeri 33 Makassar memiliki rata-rata skor total 105,98 yang termasuk dalam kategori sedang. Menurut (Purnama, 2008) sikap ilmiah dapat memberikan gambaran bersikap dalam belajar, menanggapi suatu masalah, menyelesaikan tugas dan mengembangkan diri. Hal ini tentunya dapat mempengaruhi hasil belajar peserta didik ke arah yang positif. Kurangnya sikap positif peserta didik dalam belajar dapat menyebabkan rendahnya hasil belajar peserta didik. Jadi dapat disimpulkan bahwa tingkat sikap ilmiah yang dimiliki oleh peserta didik dapat mempengaruhi hasil belajar peserta didik. Lebih lanjut Purnama menjelaskan bahwa sikap ilmiah merupakan sikap yang dibentuk oleh orang yang berkecimpung dalam ilmu alamiah dan bersifat ilmiah. Salah satu aspek tujuan dalam mempelajari ilmu alamiah adalah pembentukan sikap ilmiah.

Sikap ilmiah yang muncul dari individu disebabkan adanya rangsangan berupa suatu objek. Rangsangan itu menimbulkan respon yang konsisten baik positif/negatif, baik setuju/tidak, baik langsung/tidak, bagi individu yang bersangkutan sehinggga apabila seseorang atau peserta didik merasa tertarik, memperoleh kesempatan dan memiliki sikap menyukai suatu mata pelajaran maka akan belajar dengan baik.

Sedangkan untuk hasil belajar IPA peserta didik memiliki rata-rata skor yakni 13,35 termasuk dalam kategori sedang. Hasil belajar yang diharapkan dicapai oleh anak adalah terjadinya perubahan perilaku secara holistik. Pandangan yang menitikberatkan hasil belajar dalam bentuk penambahan pengetahuan saja merupakan wujud dari pandangan yang sempit, karena belajar dan pembelajaran harus dapat menyentuh dimensi-dimensi individual anak secara menyeluruh, termasuk dimensi emosional yang dalam waktu cukup lama luput dari perhatian. Hal ini dipandang semakin penting karena dari berbagai hasil penelitian juga menunjukan bahwa keberhasilan belajar ternyata lebih banyak ditentukan oleh faktor-faktor emosi, antara lain daya tahan, keuletan, ketelitian, disiplin rasa tanggung jawab, kemampuan menjalin kerjasama, motivasi yang tinggi serta beberapa dimensi emosional lainnya (Aunurrahman, 2012). 
Menurut Slameto (2003), faktor lain yang mempengaruhi hasil belajar peserta didik adalah sikap. Sikap merupakan sesuatu yang dipelajari, dan sikap menentukan bagaimana individu bereaksi terhadap situasi serta menentukan apa yang dicari individu dalan kehidupan. Kurangnya sikap positif peserta didik dalam belajar dapat menyebabkan rendahnya hasil belajar peserta didik.

Berdasarkan hasil analisis data untuk persamaan regresi dapat dikatakan terdapat hubungan yang positif antara sikap ilmiah terhadap hasil belajar peserta didik. Ini artinya ketika peserta didik memiliki sikap ilmiah yang baik maka, maka hasil belajar peserta didik juga akan ikut meningkat. Berdasarkan analisis data sikap ilmiah memiliki hubungan yang rendah terhadap hasil belajar peserta didik kelas VIII SMPN 33 Makassar. Hal ini dikarenakan sikap ilmiah tidak memiliki peranan yang signifikan terhadap hasil belajar. Hasil belajar peserta didik tidak sepenuhnya berasal dari sikap ilmiah peserta didik, melainkan banyak faktor-faktor lain yang dapat mempengaruhi. Namun sikap ilmiah tentu memiliki peranan terhadap peningkatan hasil belajar. Hasil penelitian sebelumnya yang dilakukan oleh Yunita, Fakhruddin, dan Nor (2013) menyatakan bahwa hubungan atau korelasi antara sikap ilmiah dan hasil belajar peserta didik rendah namun terdapat hubungan yang positif dan signifikan antara sikap ilmiah peserta didik dan hasil belajar fisika peserta didik. Sehingga dapat diartikan bahwa sikap ilmiah merupakan salah satu faktor yang mempengaruhi hasil belajar seseorang. Hasil penelitian ini juga menunjukkan subjek dalam penelitian ini memiliki tingkat sikap ilmiah tergolong positif dan memiliki hasil belajar yang tergolong sedang.

Pengaruh sikap ilmiah terhadap hasil belajar peserta didik rendah atau lemah dikarenakan ada faktor-faktor lain yang mempengaruhi hasil belajar peserta didik. Hal ini didukung oleh temuan dari penelitian lainnya. Hasil penelitian Azhari (2020) menunjukkan bahwa terdapat hubungan positif antara sikap ilmiah dengan prestasi belajar fisika dengan koefisien korelasi sebesar 0,19. Seperti pada penelitian ini korelasi antar sikap ilmiah dan hasil belajar juga berada pada kategori rendah. Hasil yang sama juga diperoleh oleh Salule (2017) yang menyimpulkan bahwa terdapat hubungan antara sikap ilmiah dengan prestasi belajar mahasiswa jurusan kimia dengan koefisien korelasi sebesar 0,26 dan koefisien determinasi sebesar 6,97\%. Jadi dapat disimpulkan bahwa tingkat sikap ilmiah yang dimiliki oleh peserta didik dapat mempengaruhi hasil belajar peserta didik. Azmi, Rahayu dan Hikmawati (2017) menjelaskan bahwa ada beberapa faktor yang menyebabkan sikap ilmiah siswa berpengaruh terhadap hasil belajar fisika siswa. Faktor yang dimakasud adalah indikator. Indikator sikap ilmiah memberikan pengaruh besar terhadap hasil belajar seperti antusias dalam mencari jawaban, tidak manipulasi data, menghargai pendapat teman, dan bekerjasama dalam kelompok ini dilakukan pada saat proses pembelajaran berlangsung sehingga memberikan pelatihan serta pembiasaan untuk menyelesaikan soal dengan baik. Hal ini dibuktikan dengan hasil analisis data sikap ilmiah yang tinggi mempunyai rerata skor hasil belaajr yang lebih besar dibanding siswa yang mempunyai sikap ilmiah rendah yaitu baik di kelas eksperimen I maupun di kelas eksperimen II. Hal ini membuktikan bahwa siswa yang memiliki sikap ilmiah tinggi akan memberikan pengaruh yang lebih besar terhadap hasil belajar jika dibandingkan dengan siswa yang mempunyai sikap ilmiah rendah.

Penelitian lain yang mendukung hasil penelitian ini dipaparkan oleh Razak dan Kamaruddin (2018) yang juga menemukan ada pengaruh yang terjadi antara sikap ilmiah dengan hasil belajar. Ini menunjukkan pengaruh yang cukup kuat dengan saling mempengaruhi, di mana sikap ilmiah siswa mempengaruhi hasil belajar, ataupun sebaliknya. Besarnya pengaruh sikap ilmiah terhadap hasil belajar dapat dilihat dari koefisien korelasinya dan $\mathrm{R}^{2}$ sebesar $40 \%$ sikap ilmiah mempengaruhi hasil belajar, sedang $60 \%$ lainnya adalah komponen pendukung lainnya. Hal tersebut dapat terjadi, dikarenakan sikap ilmiah yang terdapat pada diri siswa merupakan sikap yang tidak dipaksakan seseorang untuk bertindak dalam mempelajari sesuatu melainkan muncul dari diri siswa itu sendiri, sehingga mendorong siswa untuk mencapai tujuan belajar yaitu hasil yang tinggi dan maksimal. Sikap ilmiah siswa yang berasal dari keingintahuan siswa, kejujuran siswa, serta sikap kekritisan dalam mempelajari suatu pelajaran menjadikan siswa dalam belajar matematika akan bersungguh- 
sungguh tanpa ada paksaan dari pihak lain. Karena sikap ilmiah siswa inilah yang menjadikan siswa akan menyenangi pelajaran, sehingga hasil belajar yang diperoleh siswa akan baik.

Salah satu bentuk upaya yang dapat dilakukan untuk meningkatkan hasil belajar pada peserta didik khususnya peserta didik kelas VIII SMPN 33 Makassar dapat dilakukan dengan menumbuhkan dan menanamkan sikap ilmiah ilmiah yang positif terhadap mata pelajaran khususnya mata pelajaran IPA karena seseorang yang memiliki sikap ilmiah positif dalam belajar IPA maka akan lebih aktif sehingga dapat memperoleh hasil belajar yang baik. Kita harus memperhitungkan faktor-faktor tersebut serta dampaknya, untuk menghindari faktor yang bisa saja tidak menguntungkan bagi peserta didik sehingga dapat membantu peserta didik dalam mencapai hasil belajar yang terbaik.

Berdasarkan uraian tersebut, perlu bagi pendidik untuk memahami sikap ilmiah yang dimiliki peserta didik, serta berupaya membantu meningkatkan sikap ilmiah yang peserta didik miliki untuk meningkatkan hasil belajar peserta didik. Walaupun hubungannya tergolong rendah namun sikap ilmiah memberikan pengaruh yang positif dan signifikan yang dapat meningkatkan hasil belajar peserta didik. Hasil belajar peserta didik menunjukkan hal yang pokok dalam keberhasilan proses belajar mengajar, karena berhasil tidaknya tujuan pembelajaran bergantung pada hasil belajar peserta didik. Apabila hasil belajar peserta didik bagus menunjukkan bahwa tujuan pembelajaran juga dapat dikatakan berhasil dan sebaliknya apabila hasil belajar peserta didik kurang baik maka tujuan pembelajaran dapat dikatakan berhasil.

\section{KESIMPULAN}

Berdasarkan hasil penelitian yang dilakukan tentang studi analisis Sikap ilmiah dengan hasil belajar IPA peserta didik Kelas VIII SMP Negeri 33 Makassar disimpulkan bahwa:

1. Tingkat sikap ilmiah peserta didik kelas VIII SMP Negeri 33 Makassar memiliki rata-rata skor keseluruhan sebesar 105,98 yang termasuk dalam kategori sedang.

2. Tingkat hasil belajar IPA peserta didik kelas VIII SMP Negeri 33 Makassar memiliki rata-rata keseluruhan skor sebesar 13,35 termasuk dalam kategori sedang.

3. Terdapat hubungan yang signifikan antara sikap ilmiah dengan hasil belajar IPA peserta didik kelas VIII SMP Negeri 33 Makassar sebesar 0,333, termasuk dalam kategori rendah.

\section{DAFTAR PUSTAKA}

Anwar, H. (2009). Penilaian Sikap Ilmiah Dalam Pembelajaran Sains. Jurnal Pelangi Ilmu, Volume 2 No. 5 .

Asy'ari, M. (2006). Penerapan Pendekatan Sains-Teknologi-Masyarakat Dalam Pembelajaran Sains Di Sekolah Dasar. Jakarta: Muslichach Asy'ari. (2006). Penerapan PendekDepartemen Pendidikan Nasional Direktorat Jenderal Pendidikan Tinggi Direktorat Ketenagaan.

Aunurrahman. (2012). Belajar dan Pembelajaran. Bandung: Penerbit Alfabeta.

Azhari, S. (2020). Hubungan Antara Motivasi Belajar dan Sikap Ilmiah dengan Prestasi Belajar Fisika Siswa Kelas XI IPA SMA Negeri 2 Denpasar. Skripsi. Universitas Penidikan Ganesha. Diakses melalui: https://repo.undiksha.ac.id/id/eprint/3127. 
Azmi, M., Rahayu, S., \& Hikmawati, H. (2017). Pengaruh Model Problem Based Learning dengan Metode Eksperimen dan Diskusi Terhadap Hasil Belajar Fisika Ditinjau dari Sikap Ilmiah Siswa Kelas X MIPA SMA N 1 Mataram. Jurnal Pendidikan Fisika dan Teknologi, 2(2), 86-94. doi:http://dx.doi.org/10.29303/jpft.v2i2.294.

Salule, B. (2017). Hubungan antara Sikap Ilmiah dan Kemampuan Berpikir Logis dengan Prestasi Belajar Mahasiswa Jurusan Kimia. Skripsi. Universitas Negeri Gorontalo. Diakses melalui: https://repository.ung.ac.id/skripsi/show/441413012/hubungan-antara-sikap-ilmiah-dankemampuan-berpikir-logis-dengan-prestasi-belajar-mahasiswa-juruan-kimia.html.

Djamarah, S. B. (2006). Strategi Belajar Mengajar. Jakarta: Rineka Cipta.

Handayani, D. P. (2014). Meningkatkan Sikap Ilmiah Siswa dengan Model Project Based Learning Di Kelas VIII A SMP Negeri 8 Muaro Jambi. Jurnal Universitas Jambi.

Purnama. (2008). Ilmu Alamiah Dasar. Jakarta: PT Rineka Cipta.

Razak, F. \& Kamaruddin, R. (2018). Pengaruh Sikap Ilmiah Siswa terhadap Hasil Belajar Materi Bangun Ruang Siswa Kelas VIII SMP Negeri 3 Minasatene . Jurnal "Mosharafa", Volume 7, Nomor 1, Januari 2018 E-Issn: 2527-8827.

Sugiyono. (2015). Statistik untuk Penelitian. Bandung: Alfabeta.

Trianto. (2011). Model Pembelajaran Terpadu konsep strategi dan implementasinya Dalam Kurikulum Tingkat Satuan Pendidikan. Jakarta: Bumi Aksara.

Yunita, F., Fakhruddin, \& Nor, M. (2013). Hubungan Antara Sikap Ilmiah Siswa Dengan Hasil Belajar Fisika DI Kelas XI IPA MA Negeri Kampar. Diakses melalui : https://repository.unri.ac.id/bitstream/123456789/1508/1/Jurnal\%20Frima\%20Yunita.pdf.

\section{Abdul Rozzaq N. L.}

Mahasiswa Program Studi Pendidikan IPA FMIPA UNM, aktif melakukan penelitian pada bidang Pendidikan IPA, dapat dihubungi melalui email: rozzaq3097@gmail.com.

\section{Hasanuddin}

Dosen Program Studi Pendidikan IPA FMIPA UNM, aktif melakukan penelitian pada bidang Pendidikan IPA, dapat dihubungi melalui email: hasanuddin@gmail.com.

\section{Muhammad Aqil Rusli}

Dosen Program Studi Pendidikan IPA FMIPA UNM, aktif melakukan penelitian pada bidang Pendidikan IPA, dapat dihubungi melalui email: m.aqilrusli@gmail.com. 